
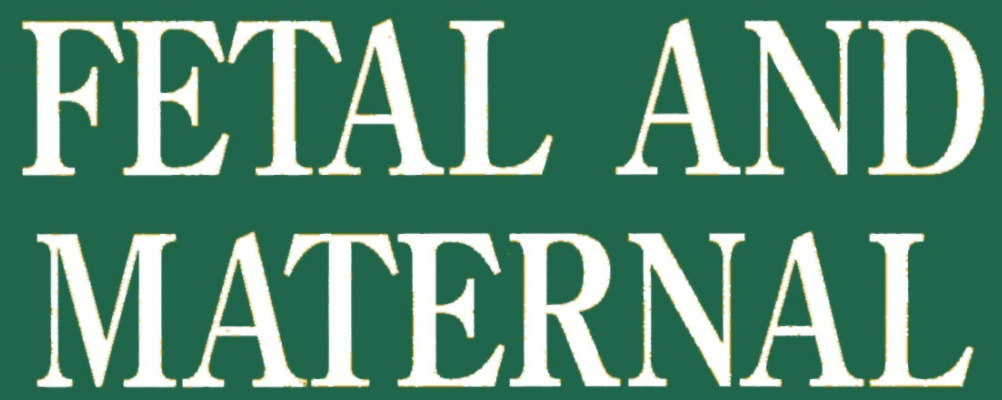

MEDICINE REVIEW 


\section{FETAL AND MATERNAL MEDICINE REVIEW}

Editor

William Dunlop Newcastle upon Tyne, UK

Assistant Editors

Stephen C Robson Newcastle upon Tyne, UK

\section{Consultant Editors}

Charles R Brinkman III Los Angeles, USA

JW Knox Ritchie Toronto, Canada

Henk CS Wallenburg Rotterdam, Netherlands

\author{
Editorial Assistant \\ Jean Birtles
}

\author{
Advisory Editorial Board \\ Andrew A Calder Edinburgh, UK \\ Allan Chang Hong Kong \\ Con A Michael Western Australia \\ E Malcolm Symonds Nottingham, UK
}

\section{Aims and scopes}

The aim of this journal is to provide information in depth about current developments in the specialty area of maternal and fetal medicine.

Articles are commissioned from authors with established international reputations as well as from those who have recently undertaken significant research. A wide range of interests is covered, including maternal physiological adaptations to pregnancy, medical disorders complicating pregnancy, pregnancy-related disease, fetal physiology and pathology and problems of the neonate.

\section{Subscriptions}

Fetal and Maternal Medicine Review (ISSN 0965-5395) is published four times a year in February, May, August and November. Four parts form a volume. The subscription price (excluding VAT) of Volume 8, 1996 is £87 net (US \$156 in USA, Canada or Mexico) for institutions, $£ 55$ (US $\$ 98$ in USA, Canada or Mexico) for individuals ordering direct from the publisher and certifying that the journal is for their individual use, post free; single parts cost $£ 24$ net (US $\$ 42$ in USA, Canada or Mexico) plus postage. EU subscribers (outside the UK) who are not registered for VAT should add VAT at their country's rate. VAT registered subscribers should provide their VAT registration number. Orders, which must be accompanied by payment, may be sent to any bookseller, subscription agent or to the publisher: Cambridge University Press, The Edinburgh Building, Shaftesbury Road, Cambridge CB2 2RU, UK, or in the USA, Canada and Mexico to Cambridge University Press, Journals Department, 40 West 20th Street, New York, NY 10011-4211, USA. Japanese prices for institutions (including ASP delivery) are available from Kinokuniya Company Ltd, P.O. Box 55, Chitose, Tokyo 156, Japan. Copies of the journal for subscribers in the USA, Canada and Mexico are sent by air to New York to arrive with minimum delay. Periodicals postage pending at New York, NY, and additional mailing offices. POSTMASTER: send address changes in USA, Canada and Mexico to Fetal and Maternal Medicine Review, Cambridge University Press, 110 Midland Avenue, Port Chester, New York, NY 10573-4930, USA.

Claims for missing issues should be made immediately on receipt of the subsequent issue.

\section{Advertising}

Apply to the publisher. Address enquiries to: Rebecca Symons (UK) or the Advertising Coordinator (USA).

\section{Copying}

This journal is registered with the Copyright Clearance Centre, 222 Rosewood Drive, Danvers, MA. 01923, USA. Organisations in the USA who are registered with the C.C.C. may therefore copy material (beyond the limits permitted by sections 107 and 108 of US copyright law) subject to payment to C.C.C. of the per-copy fee of $\$ 11.00$. This consent does not extend to multiple copying for promotional or commercial purposes. Code 0965-5395/96 $\$ 11.00+.10$

Organisations authorised by the Copyright Licensing Agency may also copy material subject to the usual conditions.

ISI Tear Sheet Service, 3501 Market Street, Philadelphia 19104, USA is authorised to supply single copies of separate articles for private use only. For all other use, permission should be sought from the Cambridge or the American Branch of Cambridge University Press.

Information on Fetal and Maternal Medicine Review and all other Cambridge journals is available on http://www.cup.cam.ac.uk/ and in North America on http://www.cup.org/ .

(C) Cambridge University Press 1996 